ISSN: $1858-4837$

E-ISSN: 2598-019X

Volume 13, Nomor 2 (2018),

https:/jurnal.uns.ac.id/region

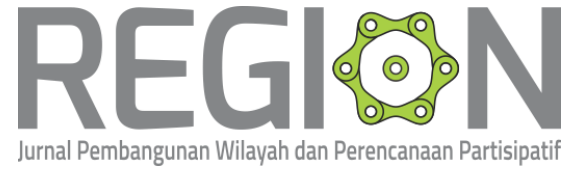

\title{
Faktor- Faktor Yang Mempengaruhi Ketersediaan Ruang Terbuka Hijau \\ Pada Setiap Dominasi Penggunaan Lahan (Studi Kasus: Kota Surakarta)
}

\section{The Factors Influencing the Availability of the Green Open Space in every Land Use Domination (Case Study: Surakarta City)}

\author{
Nida Hayu Prabowoningsiha, Rufia Andisetyana Putri ${ }^{\text {b }}$, Erma Fitria Rinic
}

${ }^{a}$ Program Studi Perencanaan Wilayah dan Kota, Fakultas Teknik, Universitas Sebelas Maret ${ }^{b}$ Program Studi Perencanaan Wilayah dan Kota, Fakultas Teknik, Universitas Sebelas Maret cProgram Studi Perencanaan Wilayah dan Kota, Fakultas Teknik, Universitas Sebelas Maret

* Corresponding author's email: nidahayul7@gmail.com

\begin{abstract}
Abstrak
Pemerintah Kota Surakarta berupaya meminimalisir emisi dengan penyediaan ruang terbuka hijau. Kondisi eksisting RTH publik sebesar $12.74 \%$ dari luas Kota Surakarta, angka tersebut menggambarkan bahwa ruang terbuka hijau eksisting di Kota Surakarta belum dapat memenuhi standar RTH publik 20\%. Selain itu, menurut Permen PU No 5 Tahun 2008 menjelaskan bahwa RTH pada karakteristik guna lahan yang berbeda, maka arahan RTH juga berbeda. Tujuan dari penelitian ini adalah untuk mengetahui faktorfaktor yang mempengaruhi ketersediaan ruang terbuka hijau pada setiap dominasi penggunaan lahan di kota surakarta. Faktor- faktor yang mempengaruhi ketersediaan ruang terbuka hijau pada setiap dominasi penggunaan lahan di Kota Surakarta, yaitu ketersediaan anggaran, alokasi ruang terbuka hijau dalam perencanaan tata ruang, implementasi rencana kerja terkait RTH, penghargaan dalam program penghijauan, pelaksana program, partisipasi masyarakat, pengaruh tokoh masyarakat, keberadaan komunitas hijau, daya serap pohon terhadap CO2, ketersediaan lahan, nilai lahan, dan pengawasan pengendalian tata guna lahan. Analisis AHP digunakan untuk mengetahui tingkatan faktor yang mempengaruhi ketersediaan ruang terbuka hijau. Hasil penelitian menunjukkan setiap dominasi penggunaan lahan industri, perumahan, perdagangan jasa, perlindungan setempat, dan ruang terbuka memiliki faktor prioritas yang berbedabeda. Faktor utama yang paling berpengaruh di zona industri adalah pengawasan pengendalian tata guna lahan, zona perumahan dan perdagangan jasa adalah alokasi ruang terbuka hijau dalam perencanaan tata ruang, zona perlindungan setempat adalah ketersediaan anggaran, sedangkan zona ruang terbuka adalah daya serap pohon terhadap CO2.
\end{abstract}

Kata Kunci: ketersediaan, faktor, penggunaan lahan, ruang terbuka hijau

\footnotetext{
Abstract

Surakarta City Government seeks to minimize emissions by providing green open space. The condition of existing public green space amounted to $12.74 \%$ of the Surakarta City, this figure illustrates that the existing green open space in Surakarta cannot meet the public green space standard 20\%. In addition, according to Minister of Public Works Decree No. 5 Year 2008 explained that green space on different land use characteristics, the direction of green space is also different. The purpose of this study is to determine
} 
the factors that influence the availability of green open spaces in every land use domination in Surakarta city. The factors affecting the availability of green open spaces in every land use domination in Surakarta City, i.e. budget availability, green open space allocation in spatial planning, implementation of RTH related work plans, awards in reforestation programs, program implementers, community participation, communities, the existence of green communities, the absorption of trees on $\mathrm{CO}_{2}$, land availability, land values, and monitoring of land use controls. AHP analysis was used to determine the level of factors that affect the availability of green open space. The results show that every land use domination of industrial land, housing, trade in services, local protection, and open space have different priority factors. The most influential factor for the industrial zone is the control of land use, for housing zones and trade in services is allocation of green open space in spatial planning, for local protection zones is the availability of budget, while for the local protection zone is the absorption of trees towards $\mathrm{CO}_{2}$.

Keywords: availability, factor, land use, green open space

\section{PENDAhULUAN}

Pertumbuhan penduduk yang tinggi di Kota Surakarta menghasilkan emisi yang tinggi. Total emisi Kota Surakarta dari berbagai sektor menurut DLH Kota Surakarta tahun 2012 sebesar 1.383.284 ton CO2e. Pemerintah Kota Surakarta berupaya meminimalisir emisi dengan penyediaan Ruang Terbuka Hijau. Menurut DLH Kota Surakarta tahun 2015, kondisi eksisting RTH publik sebesar $12.74 \%$ dari luas Kota Surakarta, angka tersebut menggambarkan bahwa ruang terbuka hijau eksisting di Kota Surakarta belum dapat memenuhi standar RTH publik 20\% menurut UU No 26 Tahun 2007. Selain itu, menurut Permen PU No 5 Tahun 2008 menjelaskan bahwa RTH pada karakteristik guna lahan yang berbeda, maka arahan RTH juga berbeda dan pada kondisi eksisting karakteristik RTH di guna lahan perdagangan jasa adalah berupa jalur hijau dengan tanaman keras, sedangkan guna lahan sempadan sungai karakteristik RTH berupa jalan inspeksi dan jalur hijau dengan tanaman yang tidak keras. Hal ini menggambarkan bahwa penyediaan RTH di Kota Surakarta untuk dominasi penggunaan lahan yang berbeda maka penyediaan RTH juga berbeda. Oleh karena itu, perlu diketahui faktor- faktor yang mempengaruhi ketersediaan ruang terbuka hijau pada setiap dominasi penggunaan lahan di Kota Surakarta.

\section{TINJAUAN PUSTAKA}

\subsection{Penggunaan Lahan}

\subsubsection{Pengertian Lahan dan Penggunaan Lahan}

Lahan adalah satu kesatuan wilayah daratan yang memiliki ciri mencakup semua karakter yang melekat pada atmosfer, tanah, geologi, tumbuhan, hidrologi, dan populasi tumbuhan dan hewan, baik yang permanen maupun yang bersifat mendaur, serta kegiatan manusia diatasnya, sehingga lahan memiliki ciri alami dan budaya. (Notohadiprawiro 1996 dalam Yuwono, 2009). Sedangkan penggunaan lahan 
Nida Hayu Prabowoningsih dkk, Faktor-faktor yang Mempengaruhi... merupakan suatu bidang lahan yang berhubungan dengan kegiatan manusia (Lillesand dan Kiefer, 1993 dalam Sajow,2015).

\subsubsection{Jenis Penggunaan Lahan}

Sadyohutomo dalam Tampi et al. (2015) mengklasifikasikan penggunaan lahan terdiri dari perumahan perdagangan, industri, jasa, taman, perairan, dan lahan kosong. Sedangkan menurut Hartshorne (1980) dalam Sajow (2015) penggunaan lahan terdiri dari Industri, permukiman, komersial, rekreasi, pendidikan dan jalan. Sedangkan menurut Malingreau (1982) dalam Sabngiarso (2008) jenis penggunaan lahan yaitu terdiri dari perairan, daerah bervegetasi, daerah tak bervegetasi, dan permukiman serta lahan bukan pertanian. Sedangkan Chapin dan Kaise (1979) dalam Marno (2016) menjelaskan bahwa lahan dapat terbagi menjadi industri, perumahan, perdagangan dan jasa, perkantoran, ruang terbuka, perairan, pertanian, rekreasi, transportasi, kuburan, perkebunan, dan pertambangan. Sedangkan menurut SNI 76542010, lahan diklasifikasikan menjadi permukiman dan lahan bukan pertanian yang berkaitan, daerah bukan pertanian, lahan terbuka, perairan, dan daerah pertanian.Terakhir dalam Permen PU no 20 Tahun 2011, penggunaan lahan terdiri dari industri, perdagangan jasa, perumahan, perlindungan setempat, ruang terbuka, perkantoran, zona peruntukkan lainnya, zona peruntukkan khusus, dan sarana pelayanan umum.

Berdasarkan teori- teori tersebut dapat disimpukan bahwa jenis penggunaan lahan yang digunakan dalam penelitian ini adalah industri, perumahan, perdagangan jasa, perlindungan setempat, dan ruang terbuka.

\subsubsection{Karakteristik Ruang Terbuka Hijau untuk setiap Penggunaan Lahan}

\subsubsection{Industri}

Menurut Permen Perindustrian No 35 Tahun 2010, karakteristik RTH untuk kawasan industri dapat berupa jalur hijau (Green Belt)dan taman. Menurut Purnomohadi (2002), jalur hijau yang mengelilingi kawasan industri (lebar 50m) dapat menurunkan polusi SO2 sebesar 70\% dan NO2 67\%. Sedangkan menurut RTRW Kota Surakarta Tahun 2011-2031, KDH industri sebesar 30\% dari luas zona industri.

Berdasarkan teori- teori tersebut dapat disimpukan bahwa karakteristik RTH pada guna lahan industri adalah memiliki $\mathrm{KDH}$ sebesar $30 \%$ dari luas zona industri dan RTH dapat berupa jalur hijau (Green Belt) dan taman.

\subsubsection{Perumahan}

Menurut Permen PU No 5 Tahun 2008, pekarangan rumah harus memiliki minimal pohon, semak, perdu dan rumput. Sedangkan menurut SNI-03-1733-2004 
Region, Vol. 13, No.2, Juli 2018: 133-151

Lingkungan perumahan harus menyediakan taman RT 250m2 untuk penduduk 250jiwa, Lingkungan perumahan harus menyediakan taman RW $1250 \mathrm{~m} 2$ untuk penduduk 2500jiwa, Lingkungan perumahan harus menyediakan taman Kelurahan 9000 m2 untuk penduduk 30000jiwa, Lingkungan perumahan harus menyediakan taman Kecamatan 24000 m2 untuk penduduk 120000 jiwa, Penyediaan jalur hijau 15m2/ penduduk yang menyebar. Sehingga dapat disimpukan bahwa karakteristik RTH pada guna lahan perumahan adalah pekarangan rumah harus memiliki minimal pohon, semak, perdu dan rumput, ketersediaan taman RT, ketersediaan taman RW, ketersediaan taman kelurahan, ketersediaan taman kecamatan, dan ketersediaan jalur hijau.

\subsubsection{Perdagangan dan jasa}

Susanti (2015) menjelaskan bahwa halaman hijau perdagangan (pertokoan rumah makan) merupakan bentuk dari RTH privat. Sedangkan menurut Permen PU no 5 Tahun 2008, penyediaan RTH pada kawasan perdagangan dan jasa diarahkan sebagai berikut : untuk KDB lebih dari 90\% maka RTH dalam bentuk taman atap bangunan, untuk bangunan yang memiliki KDB $70-90 \%$ perlu menambahkan tanaman dalam pot, untuk KDB yang lebih dari 70\% minimal memiliki dua pohon kecil atau sedang yang ditanam di lahan atau di pot dengan ukuran diameter $60 \mathrm{~cm}$, dan untuk KDB di bawah 70\% berlaku persyaratan RTH untuk pekarangan perumahan. Sehingga dapat sintesis karakteristik RTH pada guna lahan perdagangan jasa adalah ketersediaan taman atap bangunan, ketersediaan tanaman dalam pot, serta ketersediaan dua pohon kecil atau sedang yang ditanam di lahan.

\subsubsection{Ruang Terbuka}

Ruang terbuka terdiri dari ruang terbuka hijau dan ruang terbuka non hijau (Permen PU No 5 Tahun 2008). Menurut UU no 26 tahun 2007, sistem ruang terbuka terdiri dari ruang terbuka hijau dan ruang terbuka non hijau. Sama hal nya dalam Peraturan Menteri Pekerjaan Umum Nomor 12/PRT/M/2009, ruang terbuka terdiri dari ruang terbuka hijau dan ruang terbuka non hijau. Sehingga dapat disimpukan bahwa karakteristik RTH pada guna ruang terbuka adalah ruang selain ruang terbuka non hijau.

\subsubsection{Perlindungan Setempat(Perairan)}

Menurut Huda (2013), Salah satu bentuk RTH publik adalah jalur hijau di sepanjang sungai. Karakteristik RTH di sempadan sungai adalah jalur hijau yang terletak di kanan kiri sungai sebagai pelindung sungai dari berbagai gangguan dan untuk sungai di kawasan permukiman, sempadan sungai diperkirakan cukup untuk membangun jalan inspeksi 10-15m, serta dominasi tanaman tahunan (Permen PU No 5 
Nida Hayu Prabowoningsih dkk, Faktor-faktor yang Mempengaruhi...

Tahun 2008). Sehingga dapat disimpukan bahwa karakteristik RTH pada guna perlindungan setempat adalah ketersediaan jalur hijau, jalan inspeksi sungai, dan dominasi tanaman tahunan di sempadan sungai

\subsection{Ruang terbuka hijau}

\subsubsection{Pengertian, Fungsi, Tipologi, dan Jenis Ruang Terbuka Hijau}

Menurut Peraturan Menteri Pekerjaan Umum No. 5 Tahun 2008 tentang penyediaan dan pemanfaatan ruang terbuka hijau di kawasan perkotaaan, ruang terbuka hijau merupakan area memanjang/ jalur dan atau mengelompok, dengan penggunaan ruangnya yang lebih bersifat terbuka, sebagai area tumbuh tanaman, baik secara alamiah maupun sengaja ditanam. RTH memiliki fungsi yang terdiri dari fungsi utama yaitu fungsi ekologis dan fungsi tambahan yaitu fungsi sosial budaya, fungsi ekonomi, dan fungsi estetika. Tipologi ruang terbuka hijau di perkotaan dibagi menjadi empat tipologi yaitu berdasarkan fisik, fungsi, struktur, dan kepemilikan. Jenis RTH berdasarkan kepemilikan terdiri dari RTH publik dan privat.

\subsubsection{Faktor- Faktor Yang Mempengaruhi Ketersediaan Ruang Terbuka Hijau}

Kusumawardani (2017) menyatakan bahwa faktor yang berpengaruh dalam ketersediaan ruang terbuka hijau studi kasus kawasan industri yaitu yang paling utama adalah Faktor Porsi Luasan Tutupan Pohon, faktor Daya Serap Pohon terhadap CO2, dan Faktor jenis- jenis tanaman. Sedangkan menurut Kurnia (2013) faktor- faktor yang mempengaruhi kurang tersedianya ruang terbuka hijau di Kota Depok yaitu Faktor perencanaan pembangunan, Faktor implementasi rencana kerja, Keterbatasan anggaran, Lemahnya pengawasan, Faktor keterbatasan lahan, Kurangnya kesadaran masyarakat. Faktor- faktor yang mempengaruhi implementasi RTH apabila dilihat dari sisi kebijakan/hukum, terdapat faktor pendukung dan penghambat. Faktor pendukung dalam implementasi RTH adalah adanya kebijakan yang tepat yaitu alokasi RTH terhadap kebijakan tata ruang wilayah serta komitmen kota untuk mewujudkan Kota Hijau, adanya LSM yang memberikan kegiatan green action, serta ketersediaan anggaran untuk ruang terbuka hijau. Sedangkan faktor penghambat ketersediaan RTH adalah rendahnya kesadaran masyarakat dalam pemeliharaan dan pengelolaan lingkungan serta program penghijauan yang masih kurang. (Miranti et al, 2011). Sedangkan menurut Rini et al. (2014) faktor ketersediaan RTH baik di kampung maupun di perumahan formal adalah alokasi ruang terbuka hijau dalam perencanaan tata ruang, program penghijauan, koefisian dasar hijau, insentif dan disinsentif, pengawasan dan pengendalian tata guna lahan, partisipasi masyarakat, pengaruh tokoh masyarakat, kesadaran masyarakat, komunitas hijau, penghargaan dalam program reboisasi, 
Region, Vol. 13, No.2, Juli 2018: 133-151

fasilitator, dan keragaman inovasi penghijauan, sementara faktor ketersediaan rth yang berpengaruh di kampung adalah keterbatasan lahan, kepadatan perumahan, perubahan tata guna lahan, dan terbatasnya dana. Untuk faktor ketersediaan RTH di perumahan formal adalah faktor koordinasi antara instansi pemerintah dan pengembang dan juga konsep yang ditawarkan pengembang. Dan yang terakhir menurut Fattah (2011), faktor yang mempengaruhi ketersediaan rth adalah pelaksana program, keuangan, faktor ketersediaan lahan, dan nilai lahan.

Berdasarkan teori- teori tersebut dapat disimpukan bahwa faktor- faktor yang mempengaruhi ketersediaan RTH, Variabel faktor yang diteliti dalam penelitian ini antara lain:

1) Ketersediaan anggaran

2) Alokasi ruang terbuka hijau dalam perencanaan tata ruang

3) Implementasi rencana kerja terkait RTH

4) Penghargaan dalam program penghijauan

5) Pelaksana program

6) Partisipasi masyarakat

7) Pengaruh tokoh masyarakat,

8) Keberadaan Komunitas hijau

9) Daya serap pohon terhadap Co2

10) Ketersediaan lahan

11) Nilai lahan

12) Pengawasan pengendalian tata guna lahan

\section{METODE}

Pendekatan yang digunakan pada penelitian ini ialah pendekatan deduktif dengan jenis penelitian kuantitatif. Proses pengumpulan data dilakukan dengan melakukan survei primer berupa penyebaran kuesioner AHP kepada stakeholder untuk mengetahui tingkatan faktor yang mempengaruhi ketersediaan ruang terbuka hijau pada setiap dominasi penggunaan lahan di Kota Surakarta. Kuesioner disebarkan kepada 20 stakeholder kunci yang merupakan ahli atau orang yang berpengalaman dalam bidang ruang terbuka hijau pada setiap guna lahan. Data tersebut kemudian dianalisis dengan teknik analisis AHP pada software Expert Choice 11. Kerangka analisis pada penelitian ini adalah sebagai berikut. 
Nida Hayu Prabowoningsih dkk, Faktor-faktor yang Mempengaruhi...

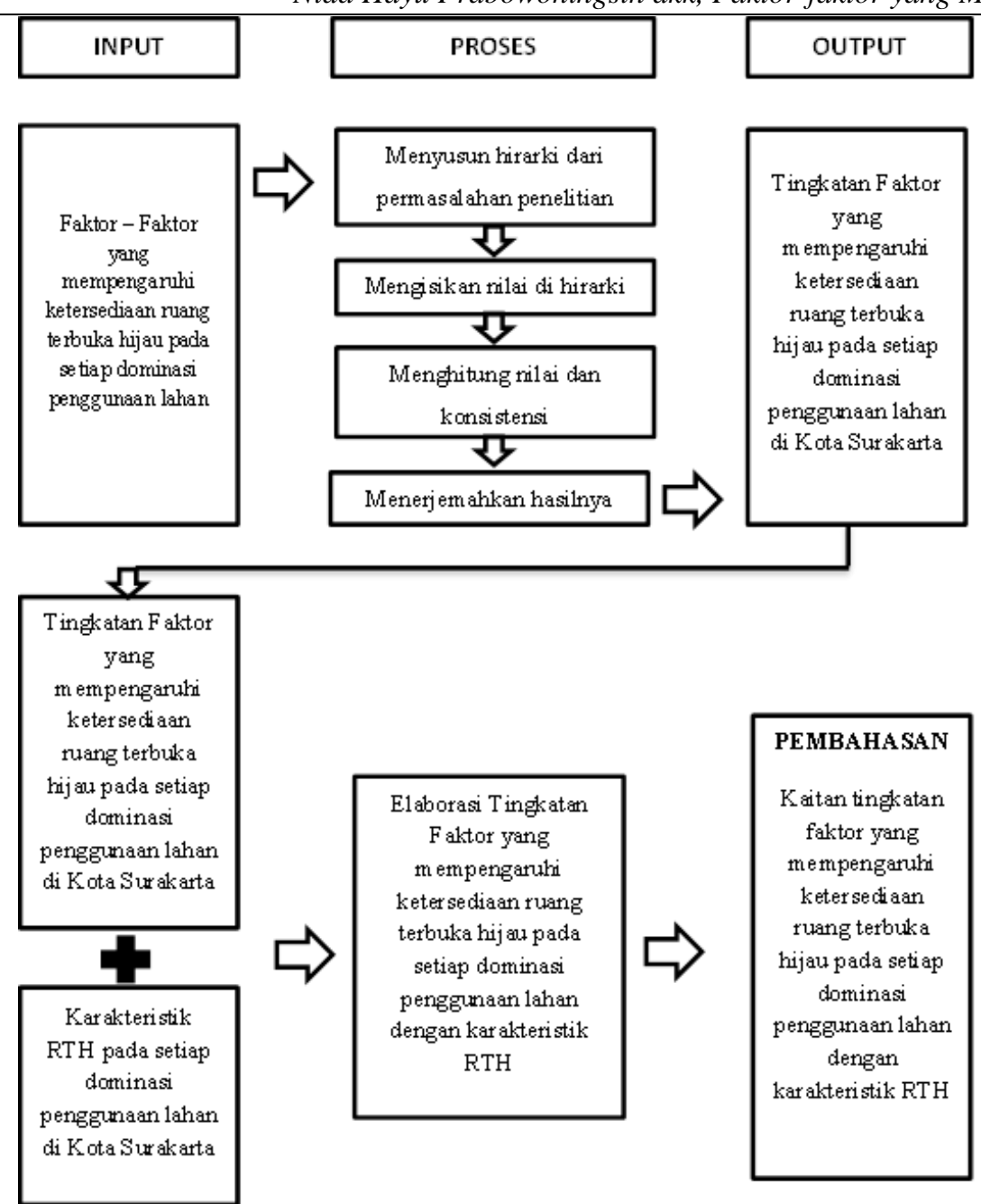

Gambar 1. Kerangka Analisis Penelitian

\section{HASIL PENELITIAN DAN PEMBAHASAN}

\subsection{Karakteristik Ruang Terbuka Hijau di Kota Surakarta}

Ruang terbuka hijau di Kota Surakarta terdiri dari berbagai jenis karakteristik, berikut ini luasan RTH eksisting Kota Surakarta tahun 2014 :

Tabel 1. Luasan RTH Eksisting Kota Surakarta Tahun 2014

\begin{tabular}{|l|l|r|r|}
\hline No & \multicolumn{1}{|c|}{ Jenis RTH } & Luas (Ha) & Persentase RTH terhadap Wilayah \\
\hline 1 & Taman Kota & 11.33 & $0.257 \%$ \\
\hline 2 & Lapangan & 63.25 & $1.436 \%$ \\
\hline 3 & Jalur Hijau Jalan & 211.01 & $4.791 \%$ \\
\hline 4 & TPU (yang dikelola DKP) & 68.76 & $1.561 \%$ \\
\hline & TPU (yang dikelola kelurahan) & 0.04 & $0.001 \%$ \\
\hline 5 & Sempadan Sungai & 77.61 & $1.762 \%$ \\
\hline & Taman Balai Sungai & 0.15 & $0.003 \%$ \\
\hline 6 & Taman Bekas TPS & 0.11 & $0.002 \%$ \\
\hline 7 & Hutan Kota (Perwali) & 49.94 & $1.134 \%$ \\
\hline 8 & $\begin{array}{l}\text { Tanah kosong diperuntukkan } \\
\text { (Privat yang terukur) }\end{array}$ & 77.23 & $1.754 \%$ \\
\hline 9 & Taman Kelurahan & 1.83 & $0.042 \%$ \\
\hline & Jumlah & $\mathbf{5 6 1 . 2 6}$ & $\mathbf{1 2 . 7 4 4 \%}$ \\
\hline
\end{tabular}

Sumber : Penyusunan Dokumen Peta Tutupan Vegetasi Kota Surakarta, 2015 
Region, Vol. 13, No.2, Juli 2018: 133-151

Data diatas menunjukkan bahwa total luas ruang terbuka hijau di Kota Surakarta adalah 561.26 Ha yaitu sekitar $12.74 \%$ terhadap total luas wilayah Kota Surakarta. Hal ini menggambarkan bahwa luasan RTH publik eksisting belum mencapai standar minimum RTH publik yaitu 20\%. Berikut peta RTH eksisting di Kota Surakarta :
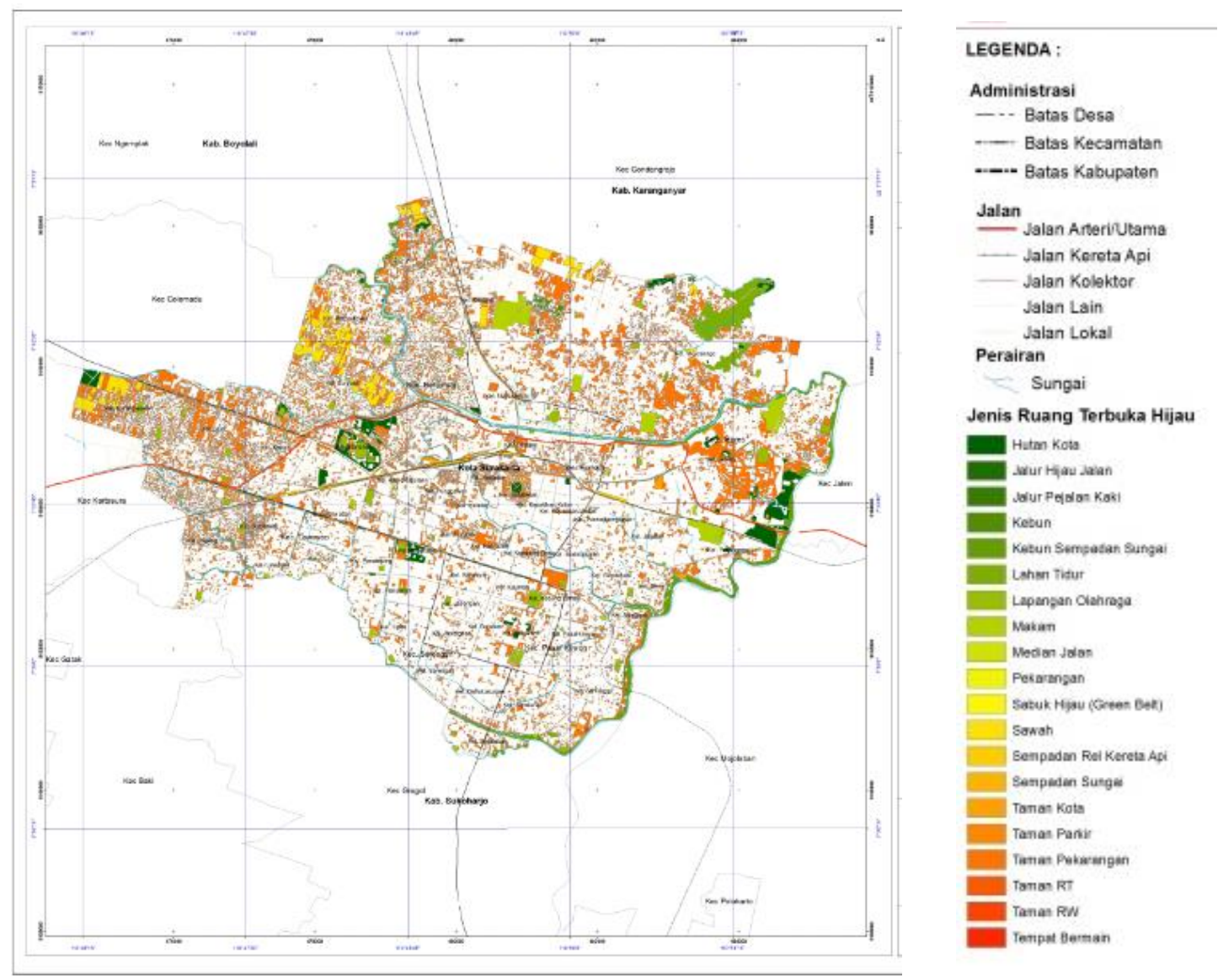

Gambar 2. Ruang Terbuka Hijau Eksisting di Kota Surakarta Sumber : Penyusunan Dokumen Peta Tutupan Vegetasi dan RTH Publik Kota Surakarta, 2015

\subsection{Karakteristik Faktor - Faktor yang Mempengaruhi Ketersediaan Ruang} Terbuka Hijau di Kota Surakarta

\subsubsection{Ketersediaan Anggaran}

Faktor ketersediaan anggaran dilihat dari data anggaran yang dikhususkan untuk penyediaan ruang terbuka hijau pada setiap dominasi penggunaan lahan di Kota Surakarta. Berdasarkan data dari DLH kota Surakarta, tercatat di tahun 2016-2018 DLH Kota Surakarta memiliki berbagai program diantaranya :

Tabel 2. Realisasi Anggaran Pembangunan dan Pengelolaan RTH Publik Tahun 2016-2018

\begin{tabular}{|c|c|c|c|c|}
\hline No & Program & Lokasi & Zona & Anggaran \\
\hline \multicolumn{5}{|c|}{ Tahun 2016} \\
\hline 1 & Revitalisasi Taman Gilingan & Gilingan, Banjarsari & Perdagangan dan Jasa & \\
\hline 2 & $\begin{array}{l}\text { Revitalisasi Taman Jurug } \\
\text { (Pembuatan taman dan Plang } \\
\text { "Kota Solo" di perbatasan } \\
\text { Karanganyar- Solo) }\end{array}$ & Jebres & Ruang Terbuka & 600 juta \\
\hline
\end{tabular}


Nida Hayu Prabowoningsih dkk, Faktor-faktor yang Mempengaruhi...

\begin{tabular}{|c|c|c|c|c|}
\hline No & Program & Lokasi & Zona & Anggaran \\
\hline 3 & $\begin{array}{l}\text { Revitalisasi Taman Banjarsari } \\
\text { (Pembangunan air mancur, } \\
\text { peningkatan instalasi dan } \\
\text { fasilitas) }\end{array}$ & $\begin{array}{l}\text { Setabelan, } \\
\text { Banjarsari }\end{array}$ & Perumahan & $2 \mathrm{M}$ \\
\hline \multicolumn{5}{|c|}{ Tahun 2017} \\
\hline 1 & Taman Mojosongo & Mojosongo, Jebres & Perumahan & $3.7 \mathrm{M}$ \\
\hline \multicolumn{5}{|c|}{ Tahun 2018} \\
\hline 1 & $\begin{array}{l}\text { Penataan Taman Jalur Hijau } \\
\text { Jl. Adi Sucipto (Segmen } \\
\text { Makuto-Fajar indah) }\end{array}$ & Kerten, Laweyan & Perdagangan dan Jasa & $1 \mathrm{M}$ \\
\hline 2 & $\begin{array}{l}\text { Rencana Pembangunan } \\
\text { Taman Gajah Putih }\end{array}$ & $\begin{array}{l}\text { Karangasem, } \\
\text { Laweyan }\end{array}$ & Perumahan & 200 juta \\
\hline 3 & Bendung karet tirtonadi & Gilingan & $\begin{array}{l}\text { Perlindungan } \\
\text { Setempat }\end{array}$ & $178 \mathrm{M}$ \\
\hline
\end{tabular}

Sumber : DLH Kota Surakarta, 2018

Berdasarkan tabel diatas, dapat diketahui anggaran untuk penataan sempadan sungai (Bendung Karet Tirtonadi) di zona perlindungan setempat memiliki nilai anggaran yang lebih tinggi daripada pembangunan di zona lain.

Untuk penyediaan ruang terbuka hijau privat baik di zona industri, zona perumahan, maupun zona perdagangan dan jasa, menjadi tanggungjawab pemilik lahan masing- masing sesuai pemanfaaatan lahannya. Di zona perumahan, alokasi anggaran untuk penyediaan ruang terbuka hijau didapatkan dari swadaya masyarakat yaitu dari iuran setiap bulan, di perumahan informal menurut data wawancara dengan warga di perumahan informal (Kelurahan Semanggi), setiap bulannya terdapat iuran untuk lingkungan sebesar Rp 10.000,- /KK. Sedangkan di perumahan formal (Kelurahan Mojosongo) sebesar Rp 20.000,--

\subsubsection{Alokasi ruang terbuka hijau dalam perencanaan tata ruang}

Faktor alokasi ruang terbuka hijau dalam perencanaan tata ruang dilihat dari aturan KDH di masing- masing dominasi penggunaan lahan di Kota Surakarta. Berikut ini aturan $\mathrm{KDH}$ di masing- masing dominasi penggunaan lahan menurut Materi Teknis RTRW Kota Surakarta 2011-2031:

Tabel 3. Aturan KDH pada Setiap Dominasi Penggunaan Lahan

\begin{tabular}{|c|l|c|}
\hline No & \multicolumn{1}{|c|}{ Zona } & Ketentuan Umum KDH \\
\hline 1 & Industri (I) & Minimal 30\% dari luas industri \\
\hline 2 & Perumahan (R) & Lebih atau sama dengan 20\% dari luas perumahan \\
\hline 3 & Perdagangan dan Jasa (P) & Minimal 30\% dari luas perdagangan jasa \\
\hline 4 & $\begin{array}{l}\text { Perlindungan Setempat } \\
\text { (Sempadan Sungai) (PS) }\end{array}$ & Minimal 20\% dari luas sempadan sungai \\
\hline 5 & Ruang Terbuka (RT) & Minimal 20\% \\
\hline
\end{tabular}

Sumber : Materi Teknis RTRW Kota Surakarta 2011-2031

Nilai KDH dari zona perlindungan setempat dan zona ruang terbuka lebih besar dikarenakan, zona tersebut didominasi oleh RTH, sehingga nilai KDH nya tinggi, 
Region, Vol. 13, No.2, Juli 2018: 133-151

sedangkan untuk perumahan, perdagangan jasa, dan industry nilai $\mathrm{KDH}$ di dapatkan dari KDB bangunan.

\subsubsection{Implementasi Rencana Kerja Terkait RTH}

Faktor ini berkaitan dengan program- program terkait ruang terbuka hijau di Kota Surakarta, baik pembangunan maupun pendekatan dengan masyarakat. Menurut data hasil wawancara dengan Ibu Rialun selaku Kepala Seksi Pertamanan DLH Kota Surakarta, dalam mengimplementasi rencana kerja terkait RTH, DLH berperan dalam kegiatan teknis, sehingga rencana penyediaan RTH bermula dari Bappeda dan Pemerintah Kota Surakarta yang mengusulkan taman mana yang akan dibangun. Setiap dominasi guna lahan memiliki rencana kerja terkait RTH kecuali untuk zona industri, karena di zona industri RTH yang disediakan bersifat privat sehingga menjadi tanggungjawab pelaku industri.

\subsubsection{Penghargaan dalam Program Penghijauan}

Berdasarkan hasil wawancara dengan Kasi Pertamanan DLH Kota Surakarta, bentuk penghargaan dalam program penghijauan bagi yang telah melaksanakan program dengan baik di setiap dominasi penggunaan lahan adalah sebagai berikut :

Tabel 4. Penghargaan Lingkungan pada Setiap Dominasi Penggunaan Lahan

\begin{tabular}{|l|l|l|}
\hline No & \multicolumn{1}{|c|}{ Zona } & \\
\hline 1 & Industri & - Pelibatan ke Green City \\
\hline 2 & Perdagangan & - Mendapatkan piagam penghargaan dari walikota \\
\hline 3 & Perumahan & - Penghargaan dari walikota untuk pemenang PROKLIM \\
& & - "Adiwiyata" untuk sekolah yang mengedepankan lingkungan \\
\hline
\end{tabular}
Sumber : Wawancara DLH Kota Surakarta, 2018

Untuk zona perlindungan setempat dan ruang terbuka, RTH yang disediakan bersifat publik sehingga menjadi tanggungjawab pemerintah Kota Surakarta.

\subsubsection{Pelaksana Program}

Pelaksana program terkait penyediaan ruang terbuka hijau publik di Kota Surakarta berdasarkan dominasi penggunaan lahan adalah sebagai berikut :

Tabel 5. Pelaksana Program RTH pada Setiap Dominasi Penggunaan Lahan

\begin{tabular}{|l|l|l|l|}
\hline No & \multicolumn{1}{|c|}{ Zona } & \multicolumn{1}{|c|}{ Program RTH } & \multicolumn{1}{|c|}{ Pelaksana Program } \\
\hline 1 & Industri & Pembangunan jalur Hijau & Pelaku Industri \\
\hline \multirow{2}{*}{2} & Perumahan & Pembangunan Taman RT & Ketua RT, masyarakat, PKK \\
\cline { 3 - 4 } & Pembangunan Taman Kelurahan & $\begin{array}{l}\text { Masyarakat, Ketua RT, RW, } \\
\text { Kelurahan }\end{array}$ \\
\hline 3 & $\begin{array}{l}\text { Perdagangan } \\
\text { dan Jasa }\end{array}$ & Pembangunan Jalur Hijau Jalan & $\begin{array}{l}\text { DLH, DPU, Bappeda, BPKAD, Dishub, } \\
\text { Kecamatan, Kelurahan, Koramil, } \\
\text { Swasta (CSR Bantuan) }\end{array}$ \\
\hline 4 & $\begin{array}{l}\text { Perlindungan } \\
\text { Setempat }\end{array}$ & $\begin{array}{l}\text { Pembangunan Jalur Hijau } \\
\text { Sempadan Sungai }\end{array}$ & $\begin{array}{l}\text { BBWS, DLH, DPU, Bappeda, BPKAD, } \\
\text { Swasta }\end{array}$ \\
\hline 5 & Ruang Terbuka & Pembangunan Taman Kota & $\begin{array}{l}\text { DLH, DPU, Bappeda, BPKAD, Dishub, } \\
\text { Kecamatan, Kelurahan, Koramil, } \\
\text { Swasta (CSR Bantuan) }\end{array}$ \\
\hline
\end{tabular}

Sumber : Wawancara DLH Kota Surakarta, 2018 
Nida Hayu Prabowoningsih dkk, Faktor-faktor yang Mempengaruhi...

\subsubsection{Partisipasi Masyarakat}

Bentuk partisipasi masyarakat dalam penyediaan ruang terbuka hijau di Kota Surakarta berdasarkan dominasi guna lahan :

Tabel 6. Partisipasi Masyarakat dalam penyediaan RTH pada Setiap Dominasi Penggunaan

\begin{tabular}{|c|c|c|c|}
\hline \multicolumn{4}{|c|}{ Lahan } \\
\hline No & Zona & Bentuk RTH & Bentuk Partisipasi Masyarakat \\
\hline 1 & Industri & - & $\begin{array}{l}\text { Pengaduan apabila terjadi pencemaran } \\
\text { lingkungan }\end{array}$ \\
\hline 2 & Perumahan & $\begin{array}{l}\text { RTH pekarangan } \\
\text { rumah }\end{array}$ & $\begin{array}{l}\text { Masyarakat melakukan penghijauan di sekitar } \\
\text { rumahnya }\end{array}$ \\
\hline 3 & Perdagangan dan Jasa & $\begin{array}{l}\text { Tanaman di area } \\
\text { perdagangan }\end{array}$ & $\begin{array}{l}\text { Pelaku usaha melakukan penghijauan dengan } \\
\text { penyediaan tanaman dalam pot, pohon, } \\
\text { rumput }\end{array}$ \\
\hline 4 & $\begin{array}{l}\text { Perlindungan } \\
\text { Setempat }\end{array}$ & $\begin{array}{l}\text { RTH Sempadan } \\
\text { Sungai }\end{array}$ & Penyediaan lahan untuk tempat alat berat \\
\hline 5 & Ruang Terbuka & $\begin{array}{l}\text { Taman Kota, } \\
\text { Hutan Kota }\end{array}$ & $\begin{array}{l}\text { Ikut menjaga keberlanjutan taman dan hutan } \\
\text { kota }\end{array}$ \\
\hline
\end{tabular}

Sumber : Wawancara dengan Kasi Konservasi DLH Kota Surakarta dan BBWS Bengawan Solo, 2018

\subsubsection{Pengaruh Tokoh Masyarakat}

Tokoh masyarakat merupakan stakeholder yang terkait dengan penyediaan RTH di setiap zona dominasi penggunaan lahan. Pada kondisi di lapangan, tokoh masyarakat hanya pada zona perumahan, yaitu Lembaga Pemberdayaan Masyarakat Kelurahan (LPMK) yang berperan sebagai wakil dari masyarakat yang memberikan usul kepada Lurah dalam kegiatan pembangunan dan kemasyarakatan. Di zona industri dan perdagangan jasa tidak ada tokoh masyarakat karena sifat RTH yang berada di dalam pabrik dan pertokoan sehingga tidak ada intervensi dari pihak luar. Untuk RTH di zona perlindungan setempat dan ruang terbuka bersifat publik sehingga menjadi tanggung jawab penuh pemerintah.

\subsubsection{Keberadaan Komunitas Hijau}

Berdasarkan hasil wawancara dengan DLH Kota Surakarta, komunitas hijau di Kota Surakarta antara lain:

- Forum Solo Hijau

Forum solo hijau mengikuti berbagai aktivitas hijau antara lain pencabutan paku di pohon, penanaman bibit, bersih- bersih sepanjang jalan Slamet Riyadi (6/17), sosialisasi Indonesia Bebas Sampah 2020 di Car Free Day Slamet Riyadi (2/18).

- Perkumpulan Ahli Lingkungan Hidup (PERALHI) cabang Solo

PERALHI pernah mengikuti berbagai aktivitas hijau antara lain pencabutan paku di pohon, penanaman bibit, bersih- bersih sepanjang jalan Slamet Riyadi (6/17).

- Sekolah Sungai Solo

Forum solo hijau mengikuti berbagai aktivitas hijau antara lain pencabutan paku di pohon, penanaman bibit, bersih- bersih sepanjang jalan Slamet Riyadi (6/17). 
- Komunitas Kresek Solo

Sosialisasi Indonesia Bebas Sampah 2020 di Car Free Day Slamet Riyadi (2/18).

\subsubsection{Daya Serap Pohon terhadap CO2}

Daya serap pohon terhadap CO2 dilihat dari data luasan tutupan vegetasi, yaitu daya serap pohon, semak, rumput, dan sawah terhadap emisi CO2 pada dominasi guna lahan di Kota Surakarta. Menurut Prasetyo et.al, 2002 dalam Pradiptiyas et.al,2011, menjelaskan bahwa vegetasi pohon memiliki daya serap lebih tinggi dibandingkan dengan semak, rumput, dan sawah. Berikut ini luasan pohon di setiap zona :Berikut persentase luasan vegetasi di setiap zona:

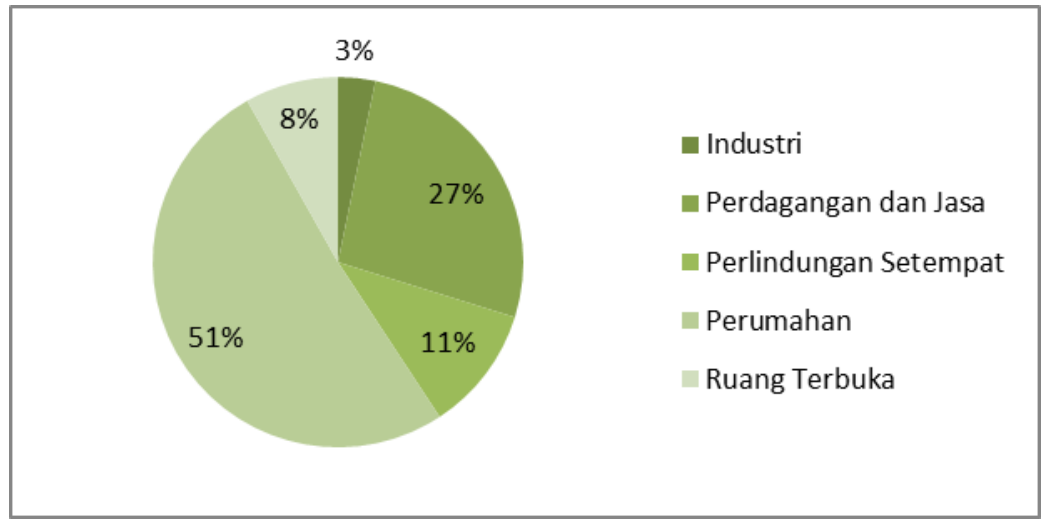

Gambar 3. Persentase Luasan Pohon di Setiap Zona Sumber : Analisis Peneliti, 2018

Diagram diatas menunjukkan bahwa, jenis vegetasi pohon tertinggi terdapat di zona perumahan, yaitu $51 \%$. Berikut peta tutupan vegetasi di Kota Surakarta :

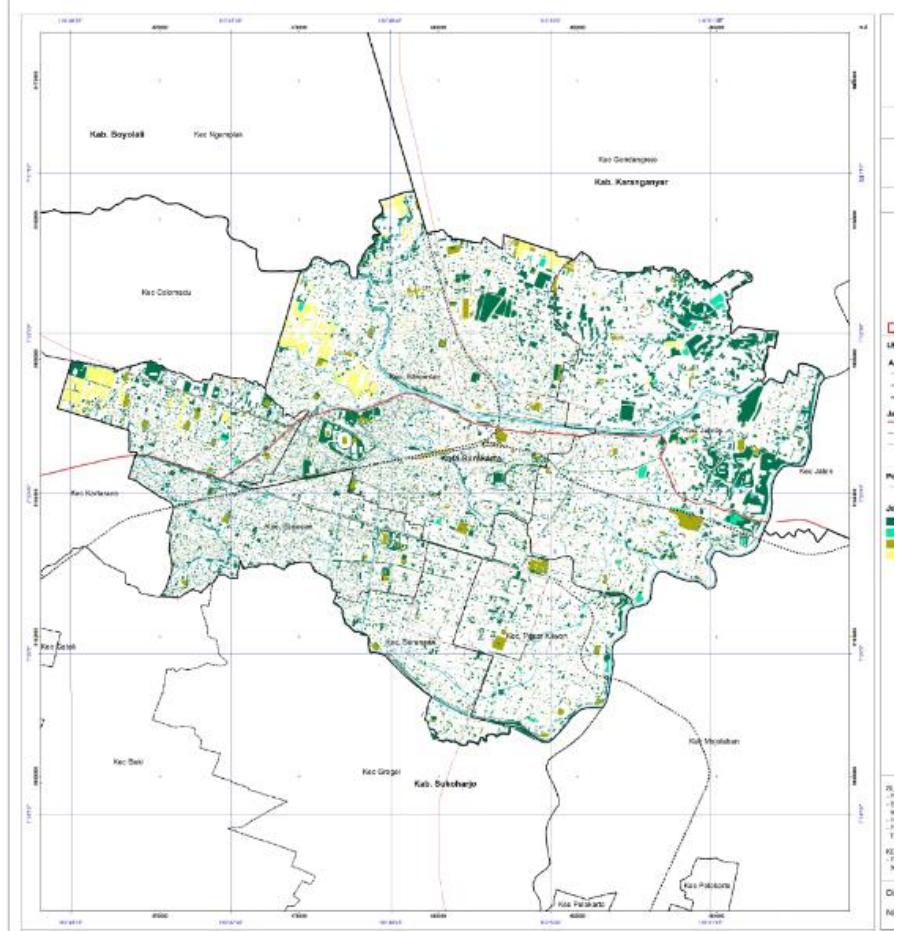

LEGENDA :

Administras

- - Batas Desa

-....... Batas Kecamatan

-"-"- Batas Kabupaten

Jalan

- Jalan Arteri/Utama

Jalan Kereta Api

Jalan Kolektor

Jalan Lain

Jalan Lokal

Perairan

S Sungai

Jenis Tutupan Vegetasi

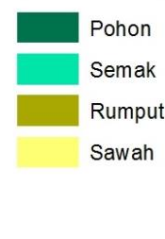

Gambar 4. Peta Jenis Tutupan Vegetasi Kota Surakarta Sumber : Citra Satelit, 2017 


\subsubsection{Ketersediaan Lahan}

Nida Hayu Prabowoningsih dkk, Faktor-faktor yang Mempengaruhi...

Faktor ketersediaan lahan didapatkan dari data lahan yang diperuntukkan untuk penyediaan ruang terbuka hijau di setiap zona dominasi penggunaan lahan di Kota Surakarta, dimana setiap dominasi penggunaan lahan di hitung dengan persentase aturan KDH yang seharusnya diperuntukkan untuk ruang terbuka hijau. Berdasarkan analisis data yang telah dilakukan, dapat diketahui bahwa RTH eksisting sebagian besar telah memenuhi aturan $\mathrm{KDH}$ di masing- masing zona dominasi penggunaan lahan. RTH yang belum sesuai dengan $\mathrm{KDH}$ adalah di zona perdagangan jasa deret dan permukiman kepadatan tinggi. Berikut persentase lahan penyediaan RTH di setiap zona:

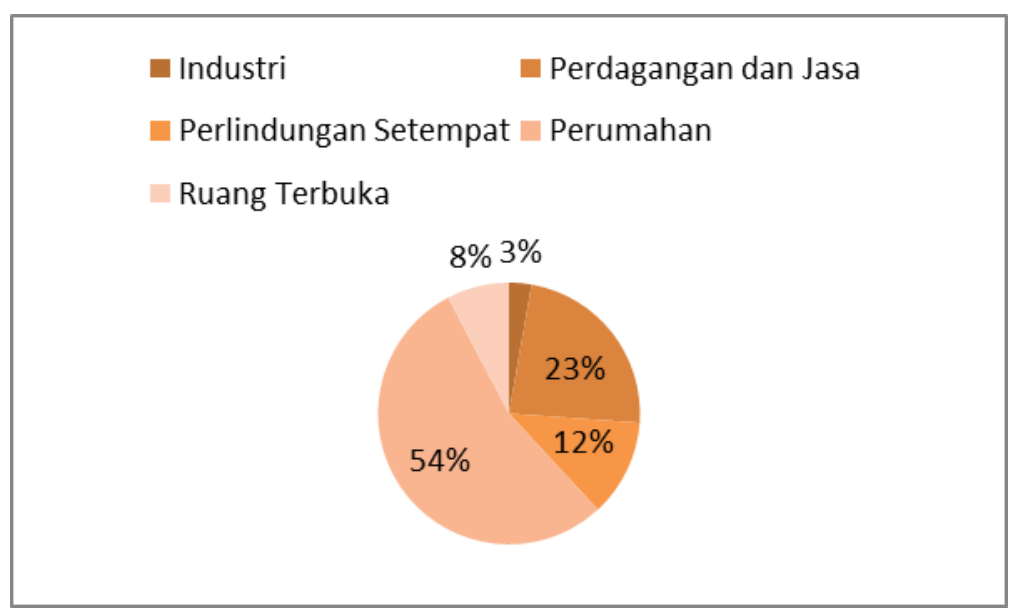

Gambar 5.Persentase Ketersediaan Lahan di Setiap Zona Sumber : Analisis Peneliti, 2018

\subsubsection{Nilai Lahan}

Nilai lahan berpengaruh dalam penyediaan ruang terbuka hijau. Berdasarkan data Peta Zona Nilai tahan Tahun 2018 (Kementerian ATR/ BPN Surakarta), sampel harga lahan di setiap zona sebagai berikut :

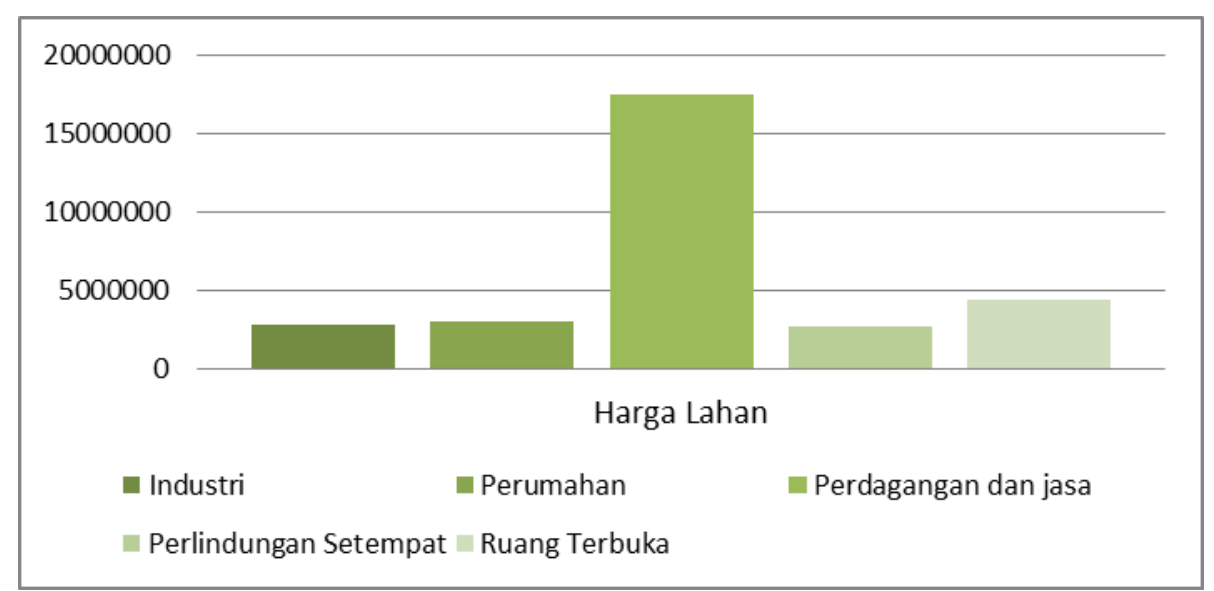

Gambar 6. Persentase Harga Lahan di Setiap Zona Guna Lahan

Sumber : : Dokumen Zona Nilai Tanah Kota Surakarta oleh ATR/BPN Kota Surakarta, 2018 
Region, Vol. 13, No.2, Juli 2018: 133-151

Berdasarkan data diatas dapat diketahui bahwa harga lahan tertinggi adalah di zona perdagangan dan jasa dikarenakan letak zona yang strategis berada di sepanjang jalan kolektor seperti di Jalan Slamet Riyadi dan Jalan Ir. Juanda (Pucangsawit, Jebres). Harga lahan terendah adalah di zona perlindungan setempat, semakin lahan dekat dengan sungai maka nilainya semakin rendah.

\subsubsection{Pengawasan Pengendalian Tata Guna Lahan}

Bentuk pengawasan pengendalian tata guna lahan menurut DLH Kota Surakarta, adalah sebagai berikut :

Tabel 7. Bentuk Pengaruh Tokoh Masyarakat dalam penyediaan RTH pada Dominasi Penggunaan Lahan

\begin{tabular}{|c|c|c|}
\hline No & Zona & Bentuk Pengawasan Pengendaliaan Tata Guna Lahan \\
\hline 1 & Industri & $\begin{array}{l}\text { - UKL/UPL dan AMDAL } \\
\text { - Apabila ada pencemaran lingkungan, seksi penegakan hukum } \\
\text { DLH mendapatkan aduan dari warga } \\
\text { - DLH menjadi mediator antara warga dengan pelaku industri } \\
\text { - Perbaikan fasilitas agar tidak mencemari lingkungan }\end{array}$ \\
\hline 2 & Perumahan & Pengawasan melalui IMB \\
\hline 3 & $\begin{array}{l}\text { Perdagangan dan } \\
\text { Jasa }\end{array}$ & Pengawasan melalui IMB, IUP (Izin Usaha Perdagangan) \\
\hline 4 & $\begin{array}{l}\text { Perlindungan } \\
\text { Setempat }\end{array}$ & $\begin{array}{l}\text { Apabila terjadi alihfungsi lahan sebagai permukiman, dilakukan } \\
\text { pembebasan lahan sempadan sungai dari permukiman (relokasi) }\end{array}$ \\
\hline 5 & Ruang Terbuka & - \\
\hline
\end{tabular}

Sumber : Wawancara dengan Kasi Konservasi DLH Kota Surakarta, 2018

\subsection{Tingkatan Faktor yang Mempengaruhi Ketersediaan Ruang Terbuka Hijau pada setiap Dominasi Penggunaan Lahan di Kota Surakarta}

Berdasarkan analisis AHP yang telah dilakukan dengan menggunakan software Expert Choice 11, dapat diketahui tingkatan faktor yang mempengaruhi ketersediaan ruang terbuka hijau pada setiap dominasi penggunaan lahan.

Priorities with respect to:

Combined

Goal: Faktor yang mempengaruhi ketersediaan RTH >Industri

Pengawasan Pengendalian tata guna lahan

Ketersediaan Iahan

Nilai lahan

Daya serap pohon terhadap CO2

Keberadaan komunitas hijau

Pengaruh tokoh masyarakat

Penghargaan dalam program penghijauan

Pelaksana program

Alokasi ruang terbuka hijau dalam perencanaan tata ruang

Partisipasi masyarakat

Implementasi rencana kerja terkait RTH

Ketersediaan anggaran

Inconsistency $=0.03$

with 0 missing judgments.

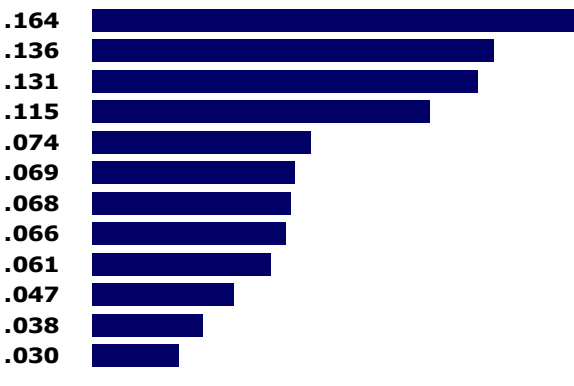

Gambar 7. Grafik Prioritas Matriks AHP Faktor RTH pada Industri Sumber : Analisis AHP (Expert Choice 11), 2018 
Goal: Faktor yang mempengaruhi ketersediaan RTH $>$ Perumahan

Alokasi ruang terbuka hijau dalam perencanaan tata ruang Ketersediaan Iahan

Keberadaan komunitas hijau

Penghargaan dalam program penghijauan

Pengawasan pengendalian tata guna lahan

Nilai lahan

Partisipasi masyarakat

Pengaruh tokoh masyarakat

Daya serap pohon terhadap $\mathrm{CO} 2$

Pelaksana program

Implementasi rencana kerja terkait RTH

Ketersediaan anggaran

Inconsistency $\mathbf{= 0 . 0 2}$

with 0 missing judgments.

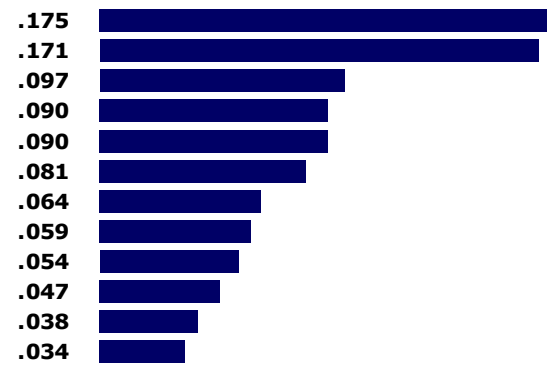

Gambar 8. Grafik Prioritas Matriks AHP Faktor RTH pada Perumahan Sumber : Analisis AHP (Expert Choice 11), 2018

Priorities with respect to:

Combined

Goal: Faktor yang mempengaruhi ketersediaan RTH $>$ Perdagangan dan Jasa
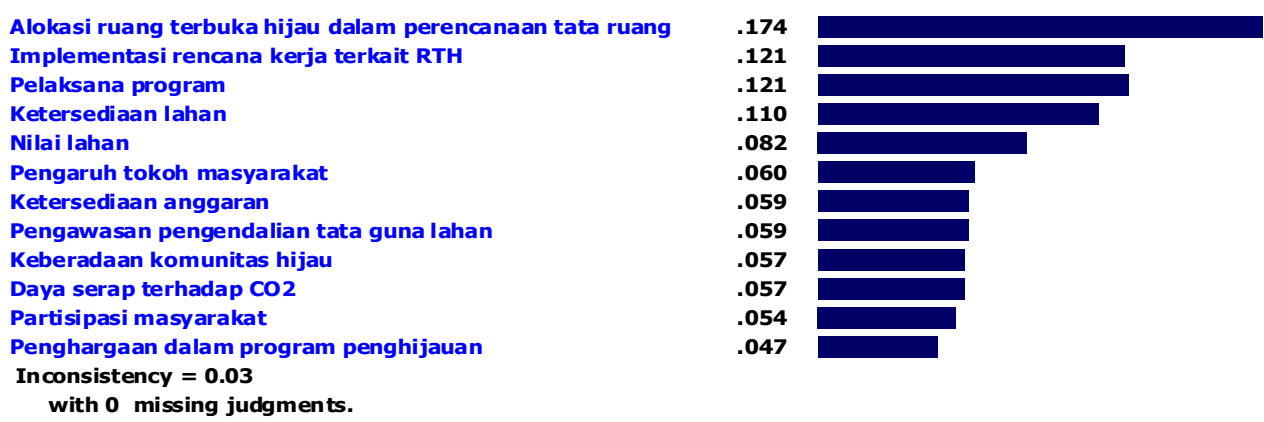

Gambar 9. Grafik Prioritas Matriks AHP Faktor RTH pada Perdagangan Jasa Sumber : Analisis AHP (Expert Choice 11), 2018

Priorities with respect to:

Ketersediaan anggaran

Alokasi ruang terbuka hijau dalam perencanaan tata ruang

Pelaksana Program

Ketersediaan lahan

Keberadaan komunitas hijau

Pengawasan pengendalian tata guna lahan

Nilai lahan

Pengaruh tokoh masyarakat

Daya serap pohon terhadap $\mathrm{CO} 2$

Partisipasi masyarakat

Implementasi rencana kerja terkait RTH

Penghargaan dalam program penghijauan

Inconsistency $=0.04$

with 0 missing judgments.

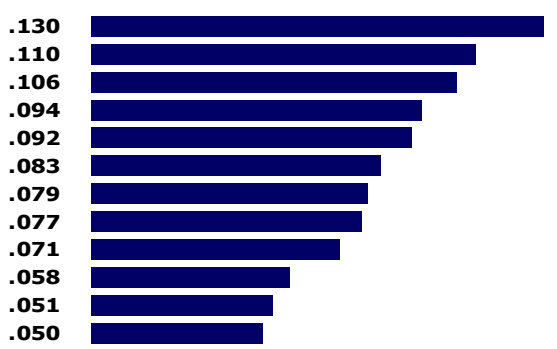

Gambar 10.Grafik Prioritas Matriks AHP Faktor RTH pada Perlindungan Setempat Sumber : Analisis AHP (Expert Choice 11), 2018 


\section{Priorities with respect to: Goal: Faktor yang mempengaruhi ketersediaan RTH $>$ Ruang Terbuka}
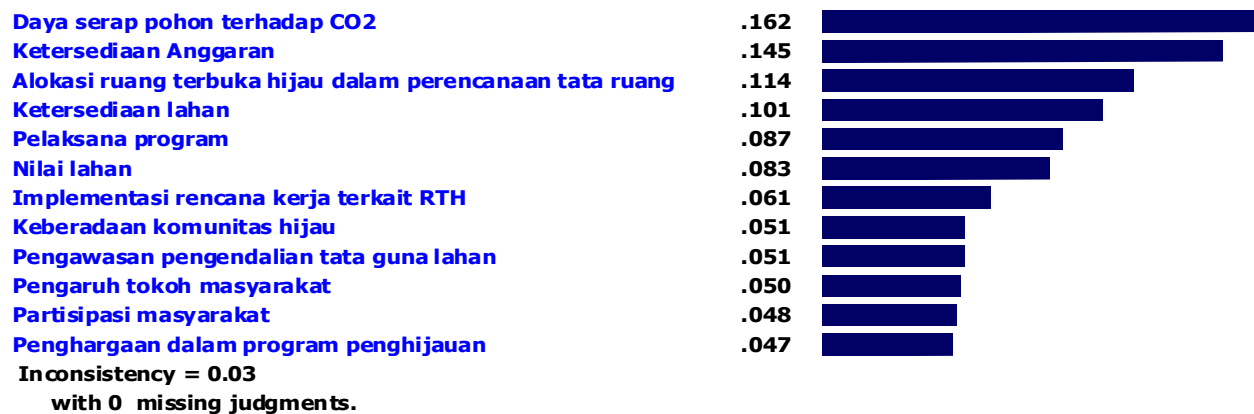

Gambar 11. Grafik Prioritas Matriks AHP Faktor RTH pada Ruang Terbuka Sumber : Analisis AHP (Expert Choice 11), 2018

Berikut ini prioritasi faktor- faktor yang mempengaruhi ketersediaan ruang terbuka hijau pada setiap dominasi penggunaan lahan di Surakarta:

Tabel 8. Prioritasi Faktor- Faktor yang Mempengaruhi Ketersediaan RTH di Kota Surakarta

\begin{tabular}{|c|c|c|c|c|}
\hline Zona Industri & Zona Perumahan & $\begin{array}{c}\text { Zona Perdagangan } \\
\text { dan Jasa }\end{array}$ & $\begin{array}{c}\text { Zona Perlindungan } \\
\text { Setempat }\end{array}$ & Zona Ruang Terbuka \\
\hline $\begin{array}{l}\text { 1. Pengawasan } \\
\text { pengendalian } \\
\text { tata guna lahan }\end{array}$ & $\begin{array}{l}\text { 1. Alokasi RTH } \\
\text { dalam } \\
\text { perencanaan tata } \\
\text { ruang }\end{array}$ & $\begin{array}{l}\text { 1. Alokasi RTH dalam } \\
\text { perencanaan tata } \\
\text { ruang }\end{array}$ & $\begin{array}{l}\text { 1. Ketersediaan } \\
\text { anggaran }\end{array}$ & $\begin{array}{l}\text { 1. Daya serap pohon } \\
\text { terhadap } \mathrm{CO} 2\end{array}$ \\
\hline $\begin{array}{l}\text { 2. Ketersediaan } \\
\text { Lahan }\end{array}$ & $\begin{array}{l}\text { 2. Ketersediaan } \\
\text { Lahan }\end{array}$ & $\begin{array}{l}\text { 2. Implementasi } \\
\text { rencana kerja terkait } \\
\text { RTH }\end{array}$ & $\begin{array}{ll}\text { 2. } & \text { Alokasi RTH } \\
& \text { dalam } \\
\text { perencanaan tata } \\
\text { ruang }\end{array}$ & $\begin{array}{l}\text { 2. Ketersediaan } \\
\text { anggaran }\end{array}$ \\
\hline 3. Nilai Lahan & $\begin{array}{ll}3 . & \text { Keberadaan } \\
\text { Komunitas } \\
\text { Hijau }\end{array}$ & 3. Pelaksana Program & $\begin{array}{l}\text { 3. Pelaksana } \\
\text { Program }\end{array}$ & $\begin{array}{ll}\text { 3. } & \text { Alokasi RTH dalam } \\
\text { perencanaan tata } \\
\text { ruang }\end{array}$ \\
\hline $\begin{array}{l}\text { 4. } \begin{array}{l}\text { Daya serap } \\
\text { pohon terhadap } \\
\mathrm{CO} 2\end{array} \\
\end{array}$ & $\begin{array}{l}\text { 4. } \begin{array}{l}\text { Penghargaan } \\
\text { dalam program } \\
\text { penghijauan }\end{array} \\
\end{array}$ & 4. Ketersediaan Lahan & $\begin{array}{l}\text { 4. Ketersediaan } \\
\text { Lahan }\end{array}$ & 4. Ketersediaan Lahan \\
\hline $\begin{array}{ll}\text { 5. } & \text { Keberadaan } \\
\text { Komunitas } \\
\text { Hijau }\end{array}$ & $\begin{array}{ll}\text { 5. } & \text { Pengawasan } \\
& \text { pengendalian } \\
\text { tata guna lahan }\end{array}$ & 5. Nilai Lahan & $\begin{array}{l}\text { 5. Keberadaan } \\
\text { Komunitas Hijau }\end{array}$ & 5. Pelaksana Program \\
\hline $\begin{array}{l}\text { 6. Pengaruh tokoh } \\
\text { masyarakat }\end{array}$ & 6. Nilai Lahan & $\begin{array}{l}\text { 6. Pengaruh tokoh } \\
\text { masyarakat }\end{array}$ & $\begin{array}{ll}\text { 6. } & \text { Pengawasan } \\
\text { pengendalian tata } \\
\text { guna lahan }\end{array}$ & 6. Nilai Lahan \\
\hline $\begin{array}{ll}\text { 7. } & \begin{array}{l}\text { Penghargaan } \\
\text { dalam program } \\
\text { penghijauan }\end{array} \\
\end{array}$ & $\begin{array}{l}\text { 7. Partisipasi } \\
\text { Masyarakat }\end{array}$ & $\begin{array}{l}\text { 7. Ketersediaan } \\
\text { anggaran }\end{array}$ & 7. Nilai Lahan & $\begin{array}{l}\text { 7. Implementasi } \\
\text { rencana kerja terkait } \\
\text { RTH }\end{array}$ \\
\hline $\begin{array}{l}\text { 8. Pelaksana } \\
\text { Program }\end{array}$ & $\begin{array}{l}\text { 8. Pengaruh tokoh } \\
\text { masyarakat }\end{array}$ & $\begin{array}{ll}\text { 8. } & \text { Pengawasan } \\
\text { pengendalian tata } \\
\text { guna lahan }\end{array}$ & $\begin{array}{l}\text { 8. Pengaruh tokoh } \\
\text { masyarakat }\end{array}$ & $\begin{array}{l}\text { 8. Keberadaan } \\
\text { Komunitas Hijau }\end{array}$ \\
\hline 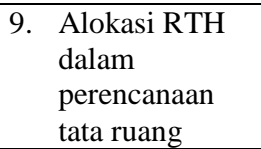 & $\begin{array}{l}\text { 9. Daya serap } \\
\text { pohon terhadap } \\
\mathrm{CO} 2\end{array}$ & $\begin{array}{l}\text { 9. Keberadaan } \\
\text { Komunitas Hijau }\end{array}$ & $\begin{array}{l}\text { 9. Daya serap pohon } \\
\text { terhadap } \mathrm{CO} 2\end{array}$ & $\begin{array}{l}\text { 9. Pengawasan } \\
\text { pengendalian tata } \\
\text { guna lahan }\end{array}$ \\
\hline $\begin{array}{l}\text { 10. Partisipasi } \\
\text { Masyarakat }\end{array}$ & $\begin{array}{l}\text { 10. Pelaksana } \\
\text { Program }\end{array}$ & $\begin{array}{l}\text { 10. Daya serap pohon } \\
\text { terhadap CO2 }\end{array}$ & $\begin{array}{l}\text { 10. Partisipasi } \\
\text { Masyarakat }\end{array}$ & $\begin{array}{l}\text { 10. Pengaruh tokoh } \\
\text { masyarakat }\end{array}$ \\
\hline $\begin{array}{l}\text { 11. Implementasi } \\
\text { rencana kerja } \\
\text { terkait RTH }\end{array}$ & $\begin{array}{l}\text { 11. Implementasi } \\
\text { rencana kerja } \\
\text { terkait RTH }\end{array}$ & $\begin{array}{l}\text { 11. Partisipasi } \\
\text { Masyarakat }\end{array}$ & $\begin{array}{l}\text { 11. Implementasi } \\
\text { rencana kerja } \\
\text { terkait RTH }\end{array}$ & $\begin{array}{l}\text { 11. Partisipasi } \\
\text { Masyarakat }\end{array}$ \\
\hline $\begin{array}{l}\text { 12. Ketersediaan } \\
\text { anggaran }\end{array}$ & $\begin{array}{l}\text { 12. Ketersediaan } \\
\text { anggaran }\end{array}$ & $\begin{array}{l}\text { 12. Penghargaan dalam } \\
\text { program } \\
\text { penghijauan }\end{array}$ & $\begin{array}{l}\text { 12. Penghargaan } \\
\text { dalam program } \\
\text { penghijauan }\end{array}$ & $\begin{array}{l}\text { 12. Penghargaan dalam } \\
\text { program } \\
\text { penghijauan }\end{array}$ \\
\hline
\end{tabular}


Nida Hayu Prabowoningsih dkk, Faktor-faktor yang Mempengaruhi...

Berdasarkan hasil analisis AHP, setiap dominasi penggunaan lahan industri, perumahan, perdagangan jasa, perlindungan setempat, dan ruang terbuka memiliki faktor prioritas yang berbeda- beda. Alokasi ruang terbuka hijau dalam perencanaan tata ruang merupakan faktor yang mempengaruhi ketersediaan RTH di sebagian besar zona kecuali di zona industri, karena dalam mencapai standar minimum RTH $30 \%$ di Kota Surakarta, penyediaan RTH di setiap zona harus memenuhi syarat KDH yang telah ditetapkan. Ketersediaan lahan juga menjadi faktor yang mempengaruhi ketersediaan RTH di zona industri dan perumahan, ketersediaan lahan untuk penyediaan RTH tergantung pemanfaatan guna lahannya, seperti halnya di zona perumahan, semakin padat permukiman semakin RTH yang disediakan sedikit.

Pelaksana program menjadi faktor yang mempengaruhi ketersediaan RTH di zona perdagangan jasa dan perlindungan setempat, apabila pelaksana program memiliki kemampuan dan menerapkan perannya masing- masing maka penyediaan RTH baik. Selain itu, ketersediaan anggaran juga menjadi faktor yang mempengaruhi ketersediaan RTH di zona perlindungan setempat dan zona ruang terbuka, hal ini dikarenakan RTH di zona perlindungan setempat dan zona ruang terbuka adalah RTH publik dan penyediaannya tergantung oleh anggaran, semakin besar anggaran RTH yang disediakan semakin baik.

\section{KESIMPULAN}

Faktor- faktor yang mempengaruhi ketersediaan ruang terbuka hijau pada setiap dominasi penggunaan lahan di Kota Surakarta dilihat dari berbagai faktor, yaitu ketersediaan anggaran, alokasi ruang terbuka hijau dalam perencanaan tata ruang, implementasi rencana kerja terkait RTH, penghargaan dalam program penghijauan, pelaksana program, partisipasi masyarakat, pengaruh tokoh masyarakat, keberadaan komunitas hijau, daya serap pohon terhadap CO2, ketersediaan lahan, nilai lahan, dan pengawasan pengendalian tata guna lahan. Berdasarkan hasil analisis AHP, setiap dominasi penggunaan lahan industri, perumahan, perdagangan jasa, perlindungan setempat, dan ruang terbuka memiliki faktor prioritas yang berbeda- beda. Faktor utama yang paling berpengaruh di zona industri adalah pengawasan pengendalian tata guna lahan, zona perumahan dan perdagangan jasa adalah alokasi ruang terbuka hijau dalam perencanaan tata ruang, zona perlindungan setempat adalah ketersediaan anggaran, sedangkan zona ruang terbuka adalah daya serap pohon terhadap CO2. 


\section{REFERENCES}

Badan Standardisasi Nasional. 2004. SNI-03-1733-2004 tentang Tata Cara Perencanaan Lingkungan Perumahan di Perkotaan. Jakarta.

Badan Standardisasi Nasional. 2010. SNI 7654-2010 tentang klasifikasi tutupan lahan. Jakarta.

DLH Kota Surakarta. (2015, September 27). Dinas Lingkungan Hidup Kota Surakarta. Retrieved from http://http://dlh.surakarta.go.id/new/?p=ss\&id=23. Diakses tanggal 12 Oktober 2017.

DLH Kota Surakarta. (2015). Penyusunan Dokumen Peta Tutupan Vegetasi dan RTH Publik Kota Surakarta.

Fattah, Q. (2001). Analisis Keberadaan Ruang Terbuka Hijau (Green Open Space) dalam Upaya mendukung Kota Medan Sebagai Kota Metropolita. Theses, Universitas Sumatera Utara.

Huda, F. N. (2012). Impelementasi Perda No. 4 Tahun 2012 Tentang Rencana Tata Ruang Wilayah Kota Tegal (Studi Penyediaan Ruang Terbuka Hijau). Journal of Politic and Government Studies, Volume 2, Nomor 2.

Kementerian Pekerjaan Umum. 2008. Peraturan Menteri Pekerjaan Umum No 5 Tahun 2008 tentang Penyediaan dan Pemanfaatan Ruang Terbuka Hijau di Kawasan Perkotaan. Jakarta.

Kementerian Pekerjaan Umum. 2009. Peraturan Menteri Pekerjaan Umum Nomor 12/PRT/M/2009 tentang Penyediaan dan Pemanfaatan Ruang Terbuka Non Hijau di Kawasan Perkotaan. Jakarta

Kementerian Pekerjaan Umum. 2011. Peraturan Menteri Pekerjaan Umum No. 20 Tahun 2011 tentang Penyusunan Rencana Detail Tata Ruang dan Peraturan Zonasi Kabupaten/ Kota. Jakarta.

Kementerian Perindustrian Republik Indonesia. 2010. Peraturan Menteri Perindustrian No 35 Tahun 2010 tentang Pedoman Teknis Kawasan Industri. Jakarta.

Kurnia, S. D. (2013). Faktor-Faktor Yang Memengaruhi Kurangnya Ketersediaan Ruang Terbuka Hijau (RTH) Publik di Kota Depok. Jurnal Ekstensi Administrasi Negara.Universitas Indonesia.

Kusumawardani, D. (2017). Arahan Penyediaan Ruang Terbuka Hijau dalam Menyerap Emisi Gas CO2 Kendaraan Bermotor pada KAwasan Industri Sier, Surabaya. Jurnal Teknik Sipil dan Perencanaan.

Marno. (2016). Pemetaan Penggunaan Lahan Kelurahan Loa Bahu Kecamatan Sungai Kunjang Kota Samarinda Menggunakan Software Arcgis 10.2.

Miranti, M., Sundarso, \& Purnaweni, H. (2011). Faktor-faktor yang Mempengaruhi Implementasi Kebijakan Ruang Terbuka Hijau di Kabupaten Rembang. 1-11.

Pemerintah Kota Surakarta. 2012. Peraturan Daerah Kota Surakarta No. 1 Tahun 2012 tentang Rencana Tata Ruang Wilayah Kota Surakarta Tahun 2011- 2031. Kota Surakarta.

Purnomohadi (2002). Pengendalian Banjir di Jakarta. Jurnal Arsitektur Lansekap Indonesia.

Rahman, M. D., Awaluddin, M., \& Hani'ah (2016). Analisis Spasial Ketersediaan Ruang Terbuka Hijau terhadap Jumlah Penduduk di Kota Solo. Jurnal Geodesi Undip, Vol. 5 No.3.

Republik Indonesia. 2007. Undang Undang No 26 Tahun 2007 tentang Penataan Ruang. Jakarta.

Rini, E. F., Sulistyarso, H., \& Pamungkas, A. (2014). Factors Influencing The Avaibility Of Green Open Space in East Surabaya. architecture \& Environtment, Vol. 13, No.1, 75-92.

Saaty, T.L. Decision Making with The Analytic Hierarchy Process, Int. J. Services. Sciences, Vol.1,No. 1, pp.83-98 
Nida Hayu Prabowoningsih dkk, Faktor-faktor yang Mempengaruhi...

Sabngiarso. (2008). Evaluasi penggunaan tanah terhadap rencana detail tata ruang Kota Semarang dengan memanfaatkan citra QuickBird :: Studi kasus pada bagian wilayah kota (BWK) VI Kecamatan Tembalang .

Sajow, H. S. (2015). Perubahan Fungsi Lahan Di Koridor Segitigamapanget-Talawaan. Universitas Sam Ratulangi Manado.

Susanti (2015). Tipologi Tata Massa Bangunan Rumah Tinggal dan Preferensi Penyediaan RTH Privat. CoUSD Proceedings. Hlm. 197-206

Tampi, D. M,. Sonny, T., \& Wuisang, C. E. V. (2015). Tata Guna Lahan di Sekitar Kawasan Bandar Udara Sam Ratulangi Manado. Jurnal ISSN: 2442-3262, Vol. 1 No.1.

Yuwono. (2009). Membangun Kesuburan Tanah di Lahan Marginal. Jurnal Ilmu Tanah dan Lingkungan, Vol.9 No.2 p:137-141. 